\title{
Circulation in the Divisional Library: The New Plan of Service
}

Mrs. Marvin is assistant librarian, Girculation Department, University of $\mathrm{Ne}$ braska Libraries.

$\mathrm{I}^{\mathrm{N}}$ THE last two decades, the American university library has had to meet the challenge of changing intellectual and academic ideals on the campus. This has been made possible through the inauguration of the divisional library plan. The University of Nebraska's divisional library is an excellent example of what can be accomplished by coordinating library service with the new teaching techniques of the university. Textbook teaching has yielded generally to independent reading assignments at $\mathrm{Ne}$ braska, as in other universities. The extensive open-shelf collections in the divisional reading rooms provide undergraduate students easy access to the many books and other printed materials which they need to consult and read.

Subject specialists in the divisional reading rooms give expert service to both undergraduate and graduate students through intimate knowledge of subject matter and library collections. The ability of the subject specialist in bibliography and in research methods is increasingly relied upon by the faculty as an extension of actual classroom instruction.

This development has involved a changed concept in library service from the old reference room, general reading room, and periodical room arrangement. There are also immediate ramifications among the circulation department's functions and serv- ices. The old ideas and methods of book circulation and the old routines of the circulation department cannot remain unaffected by these recent experiments in the organization of library service. In fact, the successful functioning of the divisional library depends in great part upon the method of circulating books from the reading rooms and the services given the student and faculty member at the circulation desk.

\section{Pivotal Position}

The University of Nebraska, one of the three pioneers in planned divisional library service on a large scale, has recognized the essential importance of the circulation department as a guidance and directional center, and as a coordinating department upon which the reading rooms depend for help in giving efficient service. The main circulation desk is, therefore, the place where any patron may come to receive aid in locating books, to ask questions about the use of the catalog and to be directed to the reading room specialist for reference assistance. The circulation department is, furthermore, the central unit of all public service, the seat of many decisions on general policies of service pertaining to all reading rooms.

The circulation department's pivotal position at Nebraska is unique when contrasted to the general notion that divisional libraries work most efficiently by decentralizing circulation, requiring each reading room to handle its separate book circulation. Such a notion stems, in part at least, from the 
idea that a reading room is a separately functioning unit. It has been emphasized again and again at Nebraska that the subject divisions, the humanities, the social studies and the sciences are intimately coordinated parts of one central library, rather than separate libraries conveniently collected under one roof. Even beyond this, the case for centralization of circulation records with general informational and guidance services makes remarkable sense in terms of both the quality of service rendered and the quantity which can be handled.

\section{In the Beginning}

Moving into a new divisional library building can be the realization of a dream for librarians, the faculty and the student body. This was certainly true at the University of Nebraska in the fall of 1945 , when the Love Memorial Library opened its doors for service. For the librarians it meant a new and rapidly expanding concept of service to be developed. For the student and faculty member it meant a new and more convenient way of finding and using books and materials.

Newness affects each person in a different way. New libraries are no exception. Would the reticent and uncertain freshman or sophomore be bewildered in the first stages of his library initiation? Would the graduate student or faculty member, disregarding the public catalog because "he knew where his books should be," and utilizing his stack privileges, be obstructed in his research when he found library materials divided between the stacks and the reading rooms? Would the splitting up of books from their general subject areas in the reading rooms into the reserve room seriously impair the student in assembling his materials? These questions were pertinent in determining circulation depart- ment policies. In no other place in the library is the question asked as of ten or as audibly, "Where is this book?"

A beginning trial period pointed the way for planning and experimentation. Initially, the circulation activities were divided between the reading rooms and the main desk. The central circulation desk on the second floor handled the book charges from the stack area only, utilizing the standard Newark system of charging, with a numerical indicator file by Dewey numbers, and a date due file of call slips.

Each of the four reading rooms (humanities, social studies, education, and science \& technology) handled its own circulation with a two-card system, requiring student assistants in each room to check out books and discharge them on return, and to control the doors. A separate closed-shelf reserve room on the ground floor, and apart from the reading rooms on the second and third floors, handled a large volume of circulation each day. The central loan desk, therefore, with few other time-consuming duties, could concentrate its efforts upon instruction in the use of the public catalog which is adjacent, and in giving general directional service.

\section{Why Centralization?}

The system described had much to recommend it. Students and faculty members responded gratefully to the aid given them by loan desk attendants in using the catalog. Wary freshmen and sophomores were guided and encouraged into a library consciousness that would prove invaluable in their university careers. Researchers and graduate students working on a thesis or dissertation found that the unlimited loan period for stack materials charged to carrells and fourth floor studies greatly facilitated their work. Was there a need for more or better service? 
Certain aspects inherent in this plan, however, did hinder the attendant at the central loan desk. Patrons invariably returned to this desk where they had first been given help, if they had difficulty in locating the books they wished. In all probability, the specific book was checked out. That the main circulation desk was the logical place to be told this may have seemed obvious to the patron. But in order to determine if the book were checked out before a further search could be made, it was necessary to send the patron back to the reading room where the file of charges was kept. A strong case could be made, therefore, to centralize all circulation files at the main desk and thereby eliminate this inconvenience.

The reserve room on the floor below presented a second and quite different problem. The filing and withdrawal of halfcards in the public catalog for books in the reserve room was a tedious and never-ending task. The volume of reserve book service increased to the point where the seating capacity of the reserve room was inadequate. Furthermore, experience had proved that often the most "live" books in many fields were tied up in the reserve room, away from the reading room where the same demand for them existed and where they could be used in conjunction with other materials.

This situation was easily and effectively obviated. The separate reserve room was abolished and turned into an unsupervised study hall. The reserve system was reorganized into a plan of overnight, threeday, and one-week reserve books which are shelved on the open shelves in the respective reading rooms on the second and third floors. This step alleviated the congestion of a reserve room, eliminated the need for continual change of the half-cards in the public catalog and brought together more books in the same subject area. The heavy demand for books in a few lower division courses in the field of the social studies was met by the installation of a small two-hour reserve desk in that area on the third floor.

The effect of these changes on the circulation routines was anticipated. The circulation records in the reading rooms immediately became complicated. Student assistants could not be held responsible for sending overdues, "call-ins," and developing a "hold" system that would insure adequate distribution of the books. The burden of reading room circulation necessarily fell upon each reading room librarian. Under this system, the fact that reading room librarians were subject specialists was of no consequence if they were forced to spend their time doing the work of clerical assistants, being bogged down with circulation activities. They had no time for real reference work or advising the students, for book selection or faculty conferences. Moreover, duplicate procedures of circulation were taking up unwarranted time in four reading rooms, procedures which could be more efficiently performed, in terms of both time and personnel, in one central department. Certainly no stronger reasons for centralizing circulation activities at the main desk could be found.

\section{The Centralized Plan is Inaugurated}

The main loan desk took over circulation activities for the whole library with little difficulty. Students brought books to the desk from the reading rooms and were charged for them. Books were returned at the same place. This change in itself was a distinct advantage for the student, who could charge and return books at the same desk instead of having to remember which room or desk they came from.

Files were not altered. Bookcards from stack books and reading room books were 
filed together in the indicator file by Dewey number, call slips by the date due. A small file of second bookcards from reading room books was established, from which each room's separate circulation statistics were compiled.

Notwithstanding the ease of conversion, this experiment in centralized circulation required courage, foresight and even ingenuity. Greater responsibility for service than is, perhaps, the goal of most circulation departments, was accepted by the department.

Circulation routines of filing, charging and discharging must be kept both efficient and simple so that these clerical tasks may be handled by competent subprofessionals, leaving the supervision and coordinating processes between the department and the reading rooms for the professional librarian. Handling a vastly increased circulation, also, must not interfere with the guidance and directional assistance given the patron at the desk. Since this service often required rechecking the catalog when a patron asked help in locating a book, desk attendants felt a dual demand on their time: to be away from the loan desk as well as giving service at it. To meet this challenge, the first step in rejuvenating circulation procedures was the creation of a file which would immediately provide the desk attendants with the location of any book in the library.

All books shelved in reading rooms were listed in this master file of location. Those not listed were automatically known to be stack books. Because the latest issues and bound volumes of the last Io years of a considerable number of periodicals are shelved in the reading rooms, a small periodical file was appended to this file. The file not only answers questions of location, but indicates what volumes are currently at the bindery. Bindery cards are filed in it on the day a shipment is sent out.

The master file card for a book shelved in a reading room contains the author's last name, the short title, call number and copy and volume numbers. Each card is stamped with the proper reading room and all cards are filed in Dewey numerical order. The file is therefore not a duplicate of the public catalog on which a patron must depend for locating his books by author or title or subject.

After the master file had been established, cards for new books added to the reading rooms were typed by the cataloging department. A card is filed just before the new book is shelved in the reading room.

At this stage in the development of routines any question of location could be answered by desk attendants in a matter of seconds. The necessity for checking the public catalog had been eliminated. While the master file worked independently, it was still necessary to check in the numerical book-card file to determine if a book were charged out.

The final and most ingenious development in the system was the consolidation of the date-due file of call slips with the master file. By filing the call slip directly in front of the master file card for the book, it became possible to determine-by checking only once and in only one file-the location of the book, whether or not it was charged out, to whom the book was charged and when it was due so that it would be available for the person desiring it.

The streamlining of the circulation routines was completed with the installation of two Gaylord electric charging machines which speeded the time of charging to a few seconds per book, and the elimination of the two-card system of charging reading room books. Only one card was now (Continued on page 265) 
for the storage of $26,600,000$ books and $6 \mathrm{I}, 000$ seats for readers. In the total scene, for every Ioo square feet of floor area for book storage there were 85 square feet for reader seating. (This ratio did not, of course, hold true for individual libraries.) About I 4 per cent of the libraries accounted for one half of the total book storage capacity, and 22 per cent accounted for one half of reader seating, indicating that many more small libraries were constructed than large ones.

\section{Average Library}

The average building provided a book storage capacity of about i 84,000 volumes and seats for 420 readers. At the time of construction, it possessed about 6I,000 volumes. The library buildings of Atlanta University, A. \& M. College of Texas and Eastern Washington College of Education came close to this statistical average.

\section{Life Expectancy}

Of I 45 library buildings erected between 1929 and 1949,63 were filled to capacity by 1949. Over one half of the buildings built between 1929 and I94I were filled by 1949. On the basis of reported growth plus extrapolated future growth, among 122 buildings for which such data were available, the average library building had a life time or life expectancy of $2 \mathrm{I}$ years. ${ }^{7}$ In other words, the average building would require a building addition for book storage 2 I years after original construction.

\footnotetext{
T Life expectancy was computed on the basis of the average rate of increase for the period extending from the year of construction to the year 1948 . The rate of increase was computed in the same fashion as compound interest is computed. If $A$ denotes the number of volumes at the time of construction and $B$ the number of volumes in 1948 , then A dollars deposited in the year of construction would yield B dollars in 1948, provided that the money accumulated only through interest compounded annually at the rate of increase characteristic for a given library. The rate of increase was acteristic for a given library. The rate of increase was
calculated only for those libraries for which the numbers $A$ and $B$ were available.
}

\section{Circulation in the Divisional Library}

\section{(Continued from page 244)}

needed, that for the bookcard file kept by date due, from which overdues were typed and circulation counted. In these two last steps, needless minutes formerly spent on bookcarding, filing and writing charges, were saved for advising and guiding the patron.

\section{Summary}

At Nebraska the centralization of all circulation activities in the divisional library at the central loan desk has meant a new concept of service to the patron. The circulation department is in a pivotal position in the library; it is the center of public service and coordination. Through the use of a master file of book location and streamlined techniques of filing and book charging, this circulation department has elevated the standards of service to patrons to a high level of quality and efficiency, and has thus contributed substantially to the success of the divisional library at the University of Nebraska. 